\title{
المواجهة في الشعر العباسي - (شعراء القرن الرابع الهجري انموجأ.
}

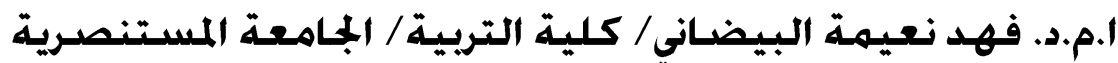

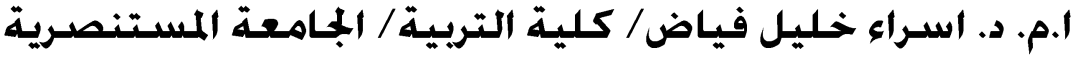

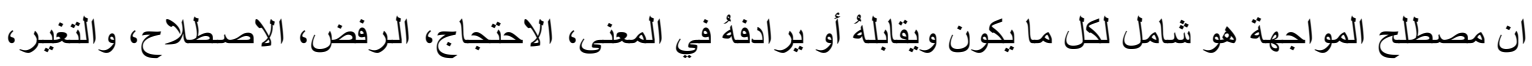

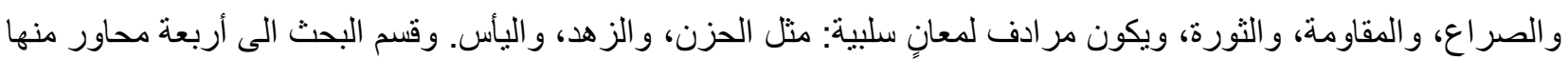
الدافع القومي الذي ظهر بسبب تسلط الغرباء على كرسي الحكم، فكان أنموذجاً المتنبي، و الثريف الرضهي ونسي اللذين هـا عربيين

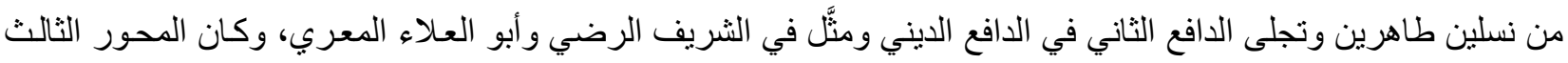
هو الدافع السياسي وما واجهت الأمة في القرن الرابع الهجري ومـا آلت إليه سياسـة البلاد، وكان ممن تصدى لهذه لهـ المرحلة

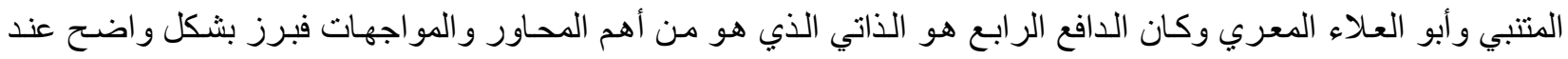
المتنبي و الثريف الرضي.

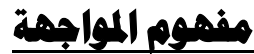

المواجهة في اللغة: هي المقابلة، والمواجهة استقبال الرجل بكلامهـ أو وجههُ، ولقيهُ وجاهاً، ومواجهة: قابل وجههُ بوجههِ|". ويكون المعنى الاصطلاحي للمواجهة هو : (الرفض) إن الثاعر والأديب في مو اقف كثيرة يرفض الحسالات السلبية في المجتمع التي لا تتفق مع الدفاهيم التي تغذى عليها من التزام في القيم السامية فنر اهُ يو اجهها بشتى الوسائل المتاحة لديه وقد تكون ردة فعلٍ تصدر منهُ حسب الظروف التي يعيشها الثاعر فنجد لديه معايير يلتزم بها. ((يقوم الالنز ام في الدرجة الأولى على الموقف الذي يتخذهُ المفكر أو الأديب أو الفنان منها، و هذا الموقف يقتضي

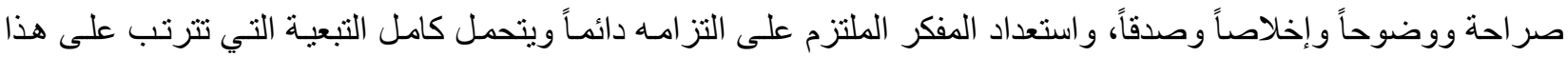
(ب) (الالنزام) (r)

التزام الثـاعر مو اقفه كأن تكون قضايا سياسية، أو اجتماعية، أو ثقافية فنر اهُ يطلق عنان الثـعر بنصرة هذه القضـايا.

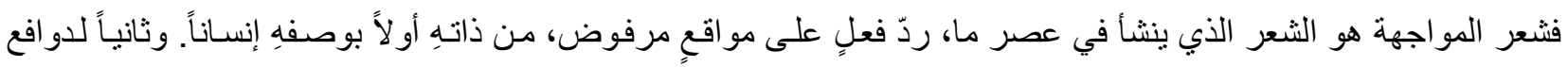

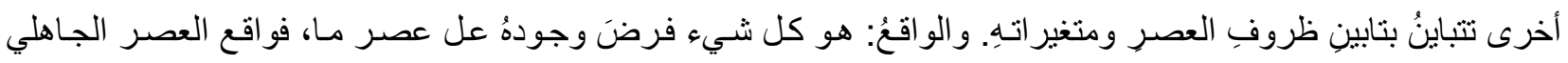

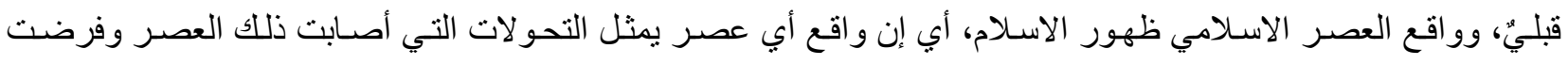
وجودها، فيكون الأدب الذي ينشأ معارضياً ومنمرداً على تللك التحو لات و المتغير ات، هو (أدب الموات اجهة) بمعنى أن المجتمع قد

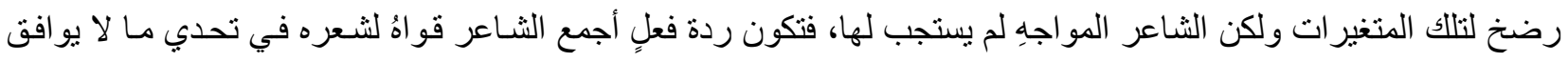

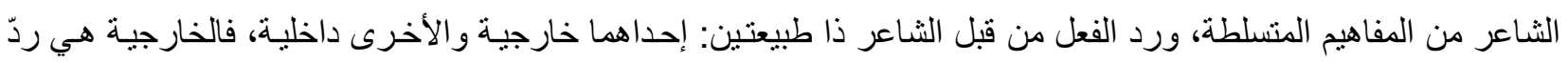

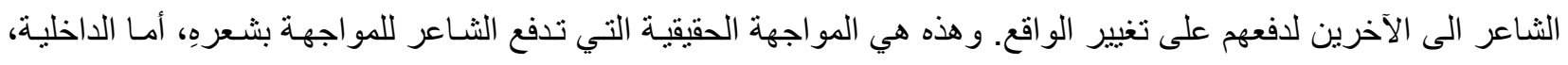
فهي التي تتحول الىى ردّ فعلٍ نفسي داخلي، أي ينطوي الثـاعر على نفسهِ وذاته مستسلماً للو اقع، لأنحُ أقوى منهُ، محتفظاً بمبادئهِ ومنهجهِ، و هذه مواجهة غير حقيقية. إذ إن للشعر و الثاعر وظيفة حقيقية اجتماعية يجب أن يؤديها إذ يكون رافضاً للو اقع في أغلب الأحيان حتى لو كان هذا الو اقع جيداً لأنه يحلم بواقع أفضل منه فهو يريد دائماً أن يحول الو اقع الى حلم و الحلم الى و اقع (بات." وتختلف المو اجهة من شاعر الى آخر ومن فئة الى أخرى باختلاف الثكل الذي تتخذهُ، ويمكن تقسيم المو اجهة على التى قسمين، الأول المباثرة أو الصريحة، والثاني غير المباشرة فهي تأخذ سبيلاً لتغيير الواقع المرفوض كمـا في شـعر الثـريف 
الرضـي أو المتنبـي أو ابن نباتـه السعدي. وهذه تمثنل الدعوة الـى تغيير الواقع المرفوض كمـا يقول ابن نباتـه السـدي ت

0 ـ ـــ (ई)

$$
\text { وأنتم ترعون تربـ البطاح }
$$

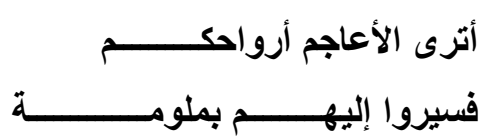

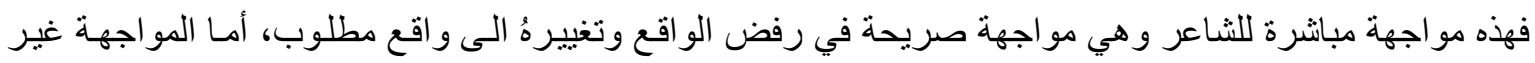

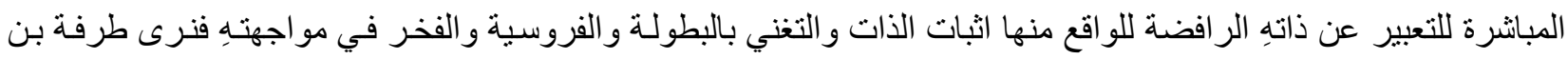
العبد).(0)

وَأَفْــــــدنُ إفراد البعير المعبد

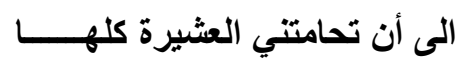

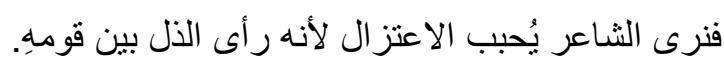

إن أدب المواجهة يفضي على الثـاعر الصدق والوضوح والاخلاص، والصدق قائم على الالنز ام. وشعر المقاومـة يختلف عن شعر المواجهة، إن المقاومة هي القوة الرئيسية التي تبعث بعدم الاستسلام للواقع من خلال التجسيد للغزو الأجنبي

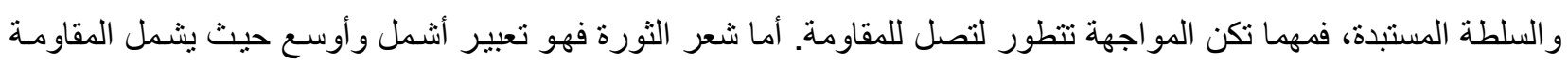

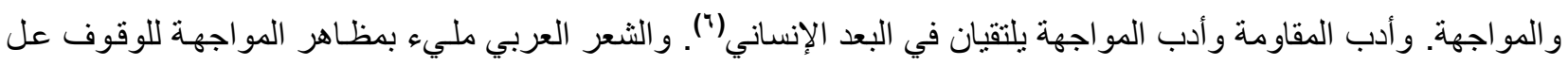

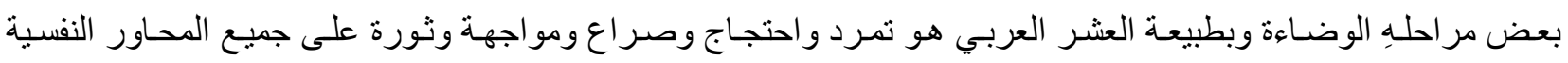

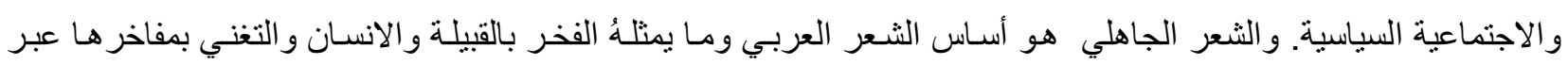

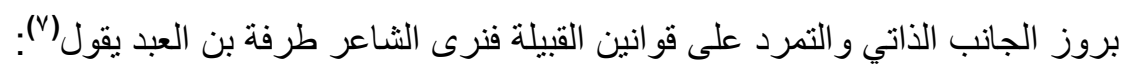
على الثَكرِ وَالتسالِ أو انـا مُقتَِّ على المرعِ من وقعِ الحُسامِ المهندِ ولكن مَولايَ امرُوءُ هو خانقي

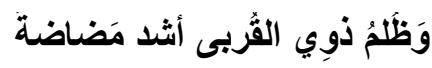

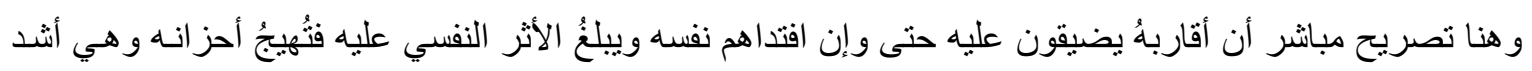

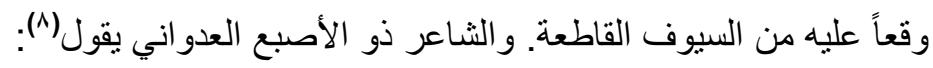
أمسى تذكر رياً أم هارون

يامن لقلب شديد الهم محزون

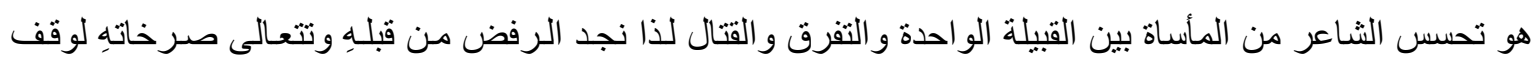

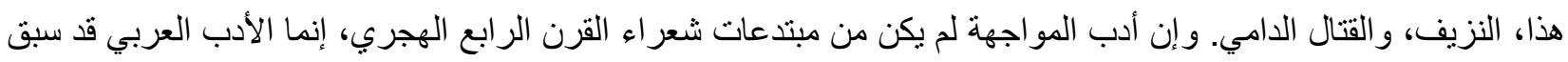

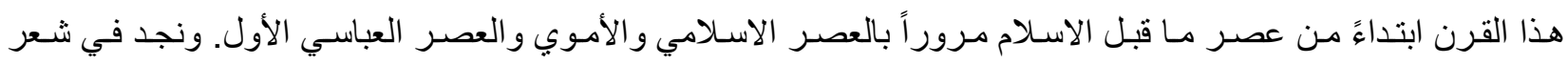

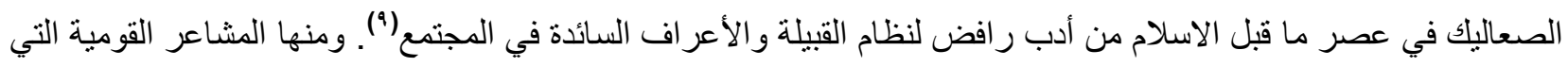

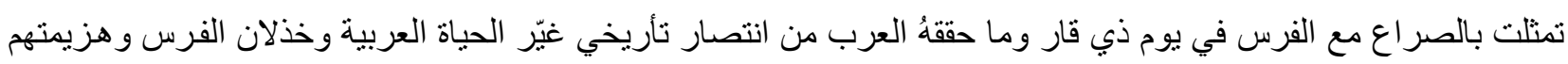

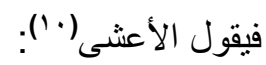

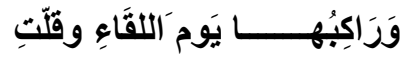

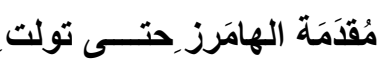

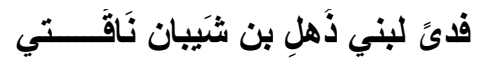

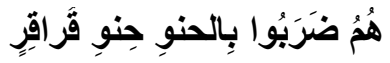

وشهد العصر الأموي ألو اناً من شعر المواجهة من طبيعة الحكم والموقف منـهُ ونقدهِ وسلبيات الحياة الاجتماعيـة

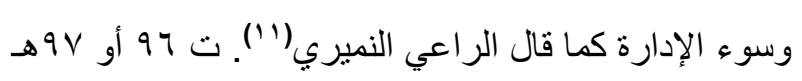

شكـــــــى إليكَّ مُظلة وعَويلا

أبلغ أميرَ المؤمنينَ رسالـــــــة 


\section{لـــــو يستطيعُ الى اللقاء سبيلا \\ من نازحِ كثَرت إليكَ هُمومهُ \\ حـــقُ الزكاةِ مُنز لاً تنزيلا \\ عربّ نرى الله في أمـــــــوالنا}

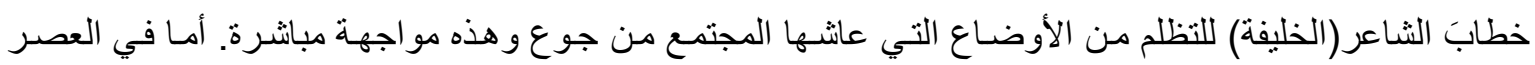

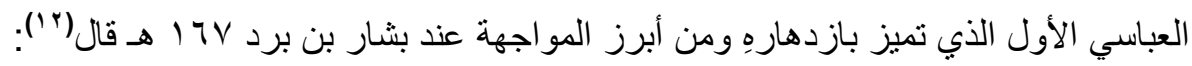

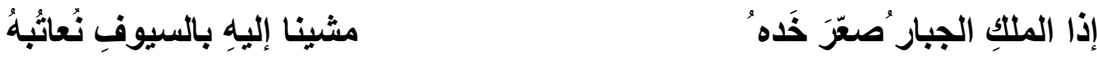

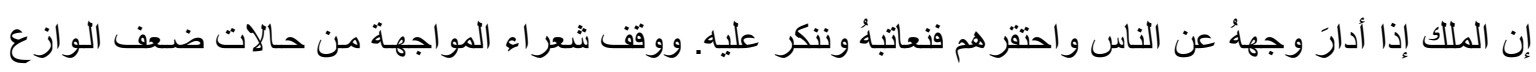

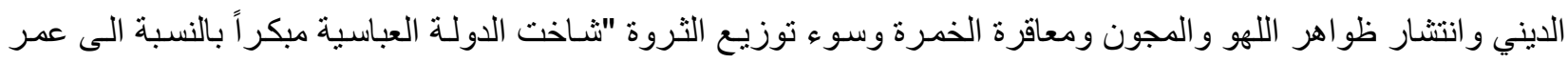
الدولة فلم يمضِ عليها أكثر من ربع قرن إلا وبانت عليها مظاهر الانحلال والتجزئة. ويوم حل عهذ المعتصم بن الرشيد صـار

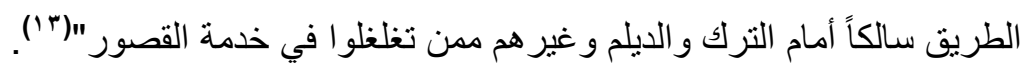

إن حالـة الإحبـاط التـي عاثـها المجتمع العربي في العصـر العباسـي في القرن الرابع الهجري هو عصـر تقلبـات

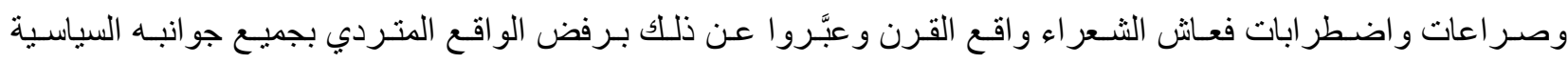
و الاجتماعية والاقتصادية والدينية وقد أستغل الثعر اء المناسبات للتعبير عما آلت إليه الأمور.

$$
\begin{aligned}
& \text { فتم تقسيم البحث على أربعة محاور وهي : } \\
& \text { المحور الأول: الدوافع القومية } \\
& \text { المحور الثاني: الدو افع الدينية } \\
& \text { المحور الثالث: الدوافع السياسية. } \\
& \text { الدحور الر ابع: الدو افع الذاتية. }
\end{aligned}
$$

المهور الأول

في الحقيقة أن كل شاعر في العصر العباسي يكاد يكون ظاهرة مو اجهة، ولكن هناك بعض أغر اض الثـر العباسي

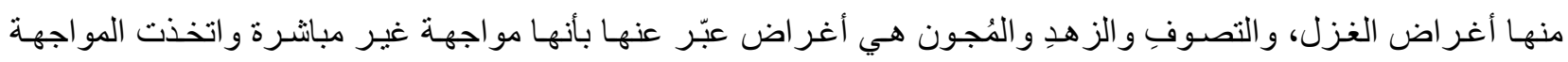

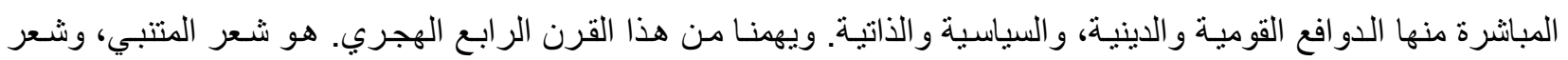

$$
\text { الشريف الرضي كونهما علويين ومن أهم دو افع المواجهة: }
$$

هذا العصر من أخطر العصور التي أُبتليت بها الأمة بسبب ضعف هيبة الدولة العباسية فبعد أن كان الخليفة العباسي

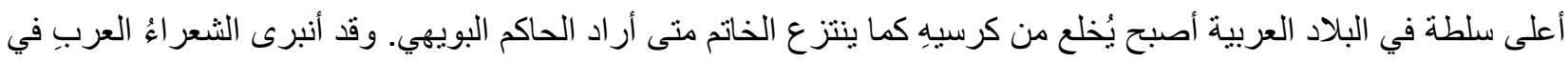

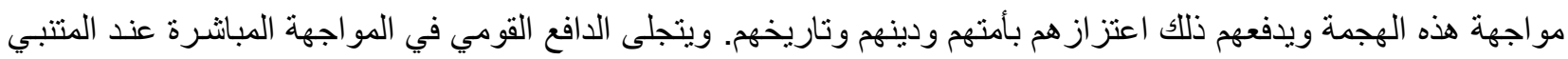

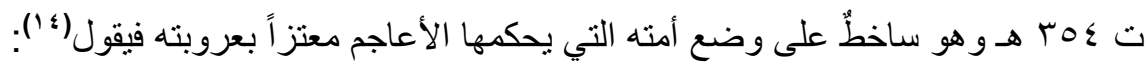

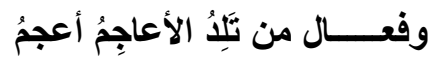

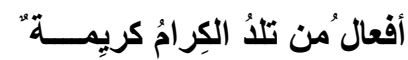

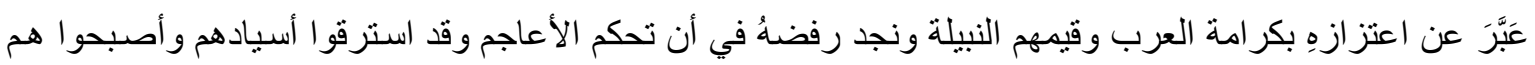

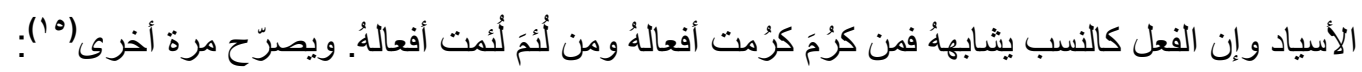

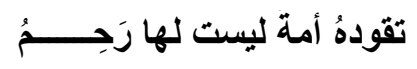

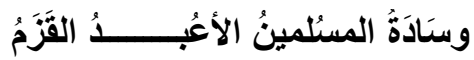

لا شيءَ أقبَحُ من فحلِ لَهُ ذَكــــرُ

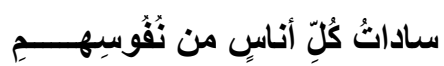




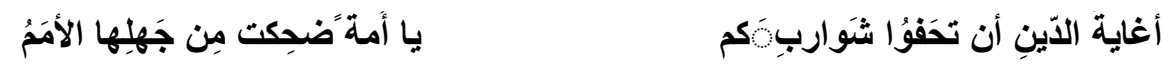

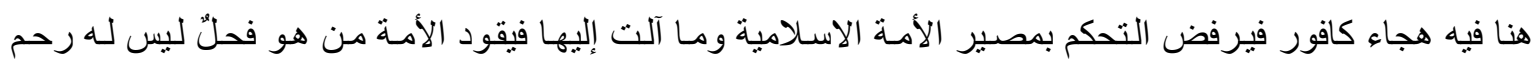

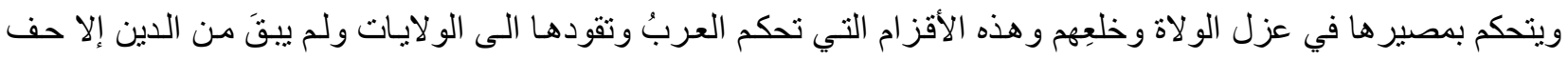

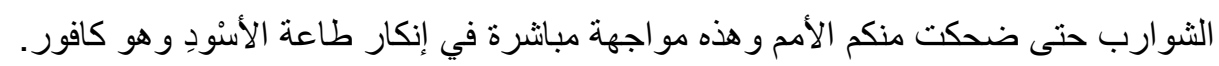
في النص المذكور تعبير صريح عن نزعة بدويـة حفز الثـاعر جنوده وإن أرض أعدائنا تتحول الى سـاحة تبرهن

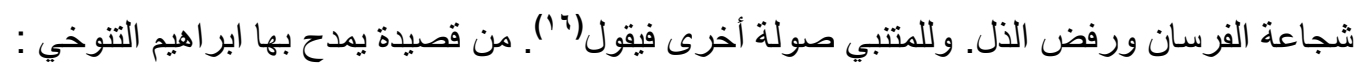

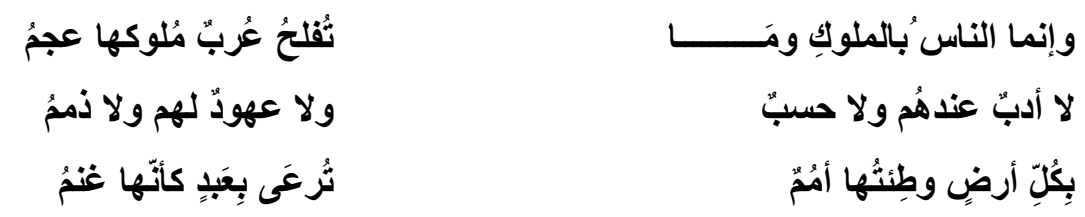

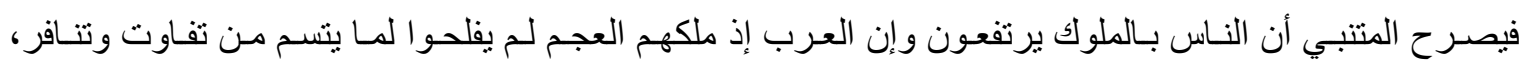

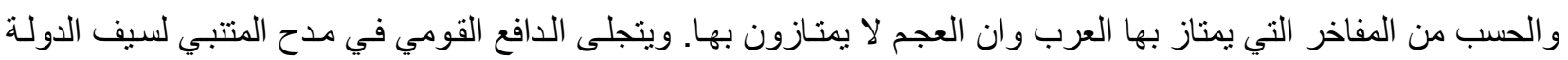

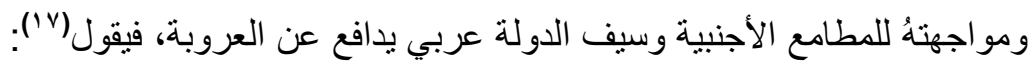

$$
\begin{aligned}
& \text { قــــــــــَ الملوكَ مواقَِ النيران } \\
& \text { أنســــــاب أصلهم الى عدنانِ } \\
& \text { أصبحــــت مِن قتتلاك الاحسانِ } \\
& \text { وإذا مدحتك صار فيك لسان. }
\end{aligned}
$$$$
\text { رَفَعت بك العَرَبُ العمِادَ وصَيَرت }
$$$$
\text { أنسابُ فخر هِم إليك وإنمتـــــا }
$$

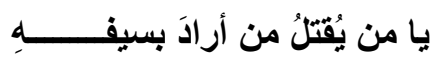

فإذا رأيتكَ صار دُنتك ناظري

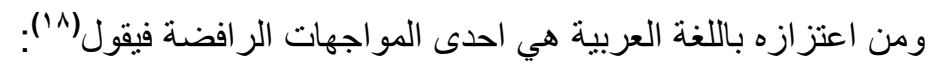

تؤُليه خيراً واللسان فصيح جُهُ المُقِلِّ فكيفَ بابن كريمةٍ

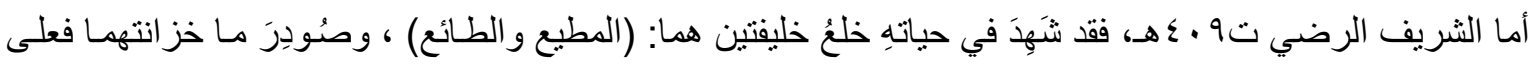

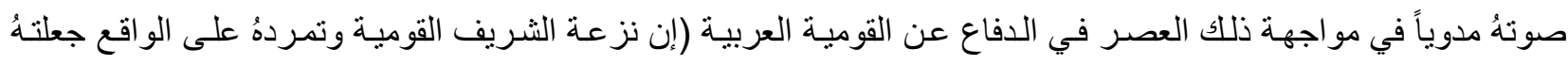

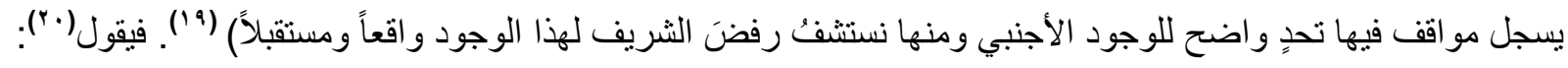

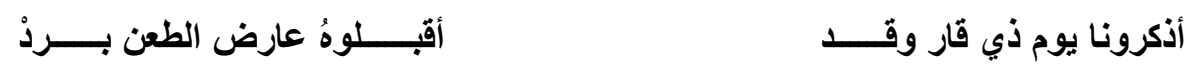

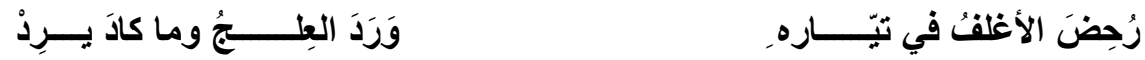

فعبّر الثريف في مواجهة ورفض و اقع الأمة وذكّر هم بيوم ذي قار التي أحتلت مكانـة جميلـة وذكريـات لا تتسى من ونس

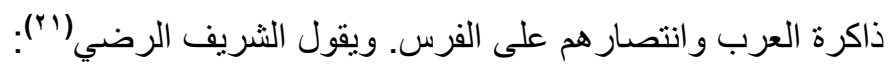
وكَمْ على الأَلَ إقرَرارّ وإذعانُ
كم اصطبار على ضيمٍٍ ومنقصَةٍ

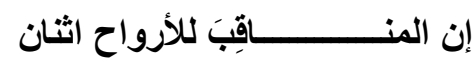

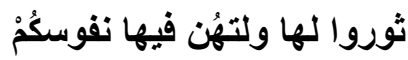

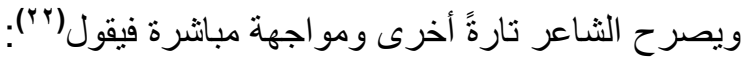

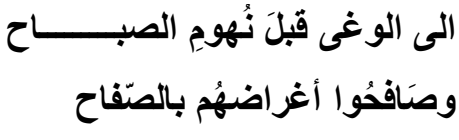

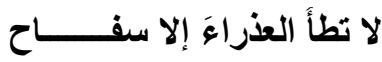

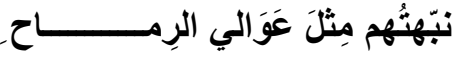

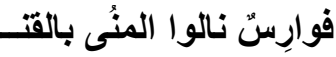

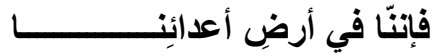




\section{ب الدافع الديني}

في سبات الأمة وجهالها وظهور الاسلام ودخول صوتهِ في مسامع العرب وشروق شمس جديدة على العرب وحملوه

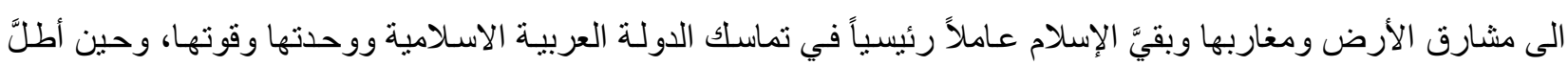

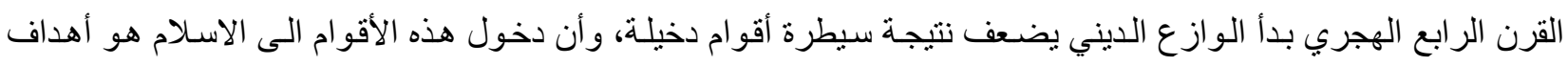

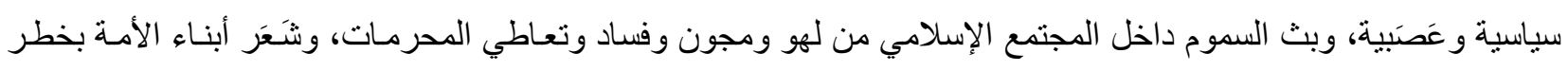

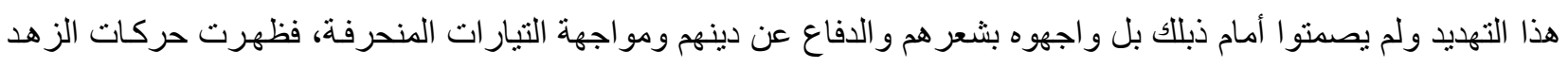

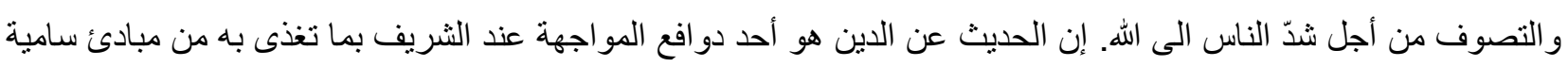

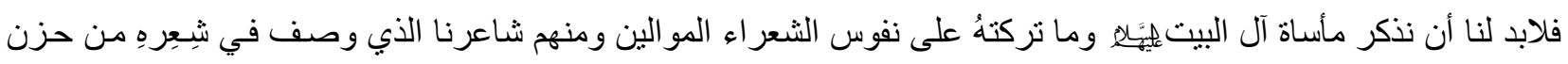

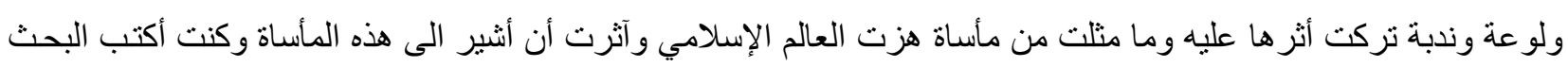

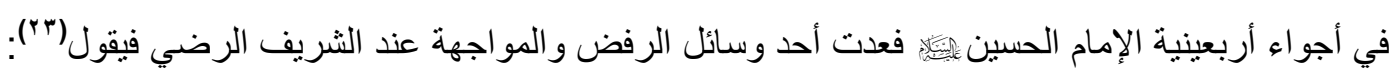

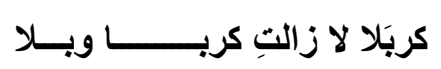

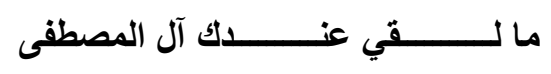

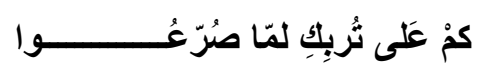

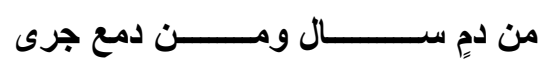
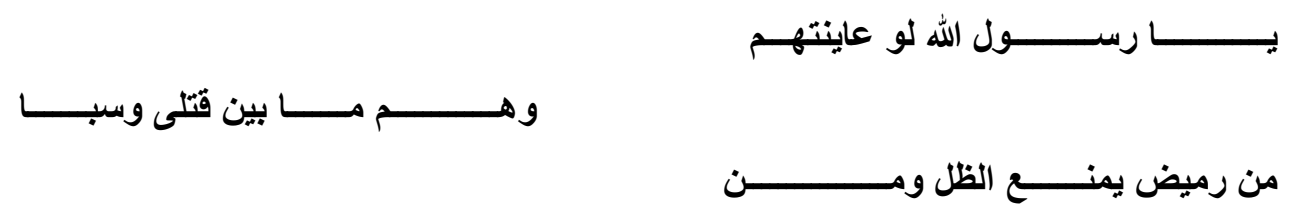

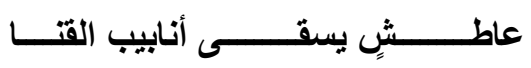
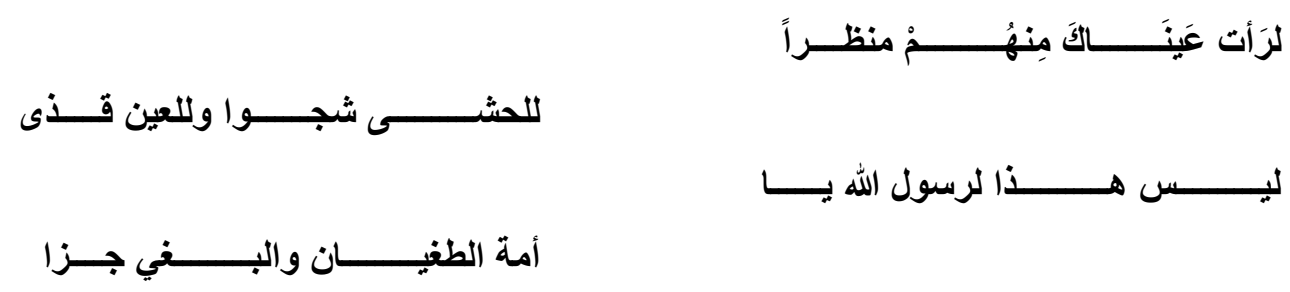

$$
\text { فنرى صوت الثريف الرضي يصدح بشعره فيقول( }
$$

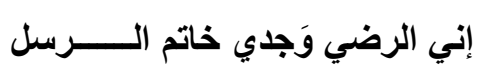

ما عذَ مثلي في نقصِ وقولتــــــهُ

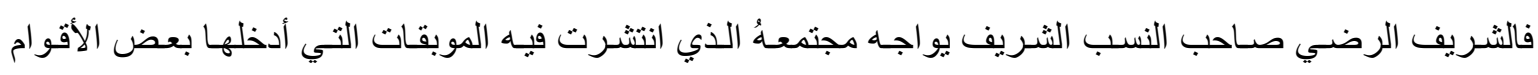

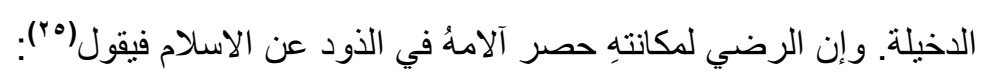

أو عُظم الأمر فصبرٌ جميل

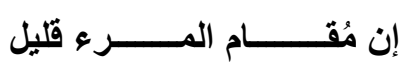

وحسبُنا الله ونعم الوكيل

$$
\text { إن آثِرَ الخطب فلا روعة }
$$
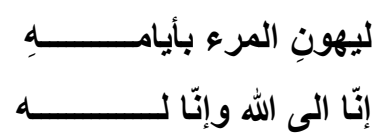

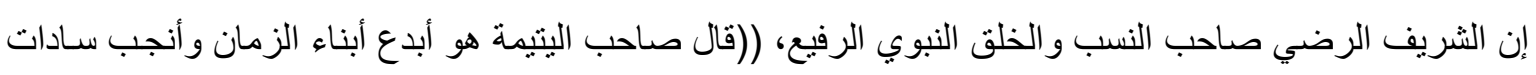

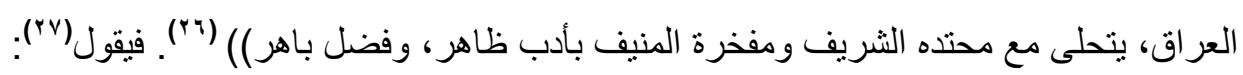

و وعِرضُهُ آمن من هَاجِراتِ فمي

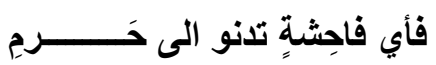

إذا العَدَّو عصصاني خَاف حَّ يـدي

جَعلتُ سمعي على قول الخنا حَرَماً 
يكادُ أنفي إذا ما استاف مرتبة

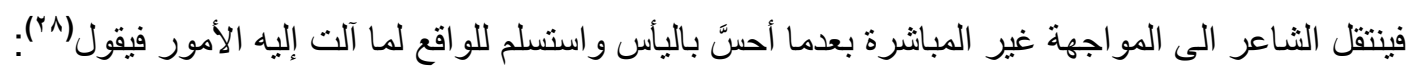

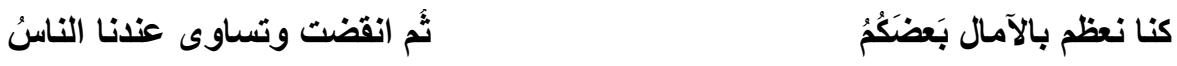

$$
\begin{aligned}
& \text { لَمَ تفضلونـا بشيعٍ غير واحسـدةٍ }
\end{aligned}
$$

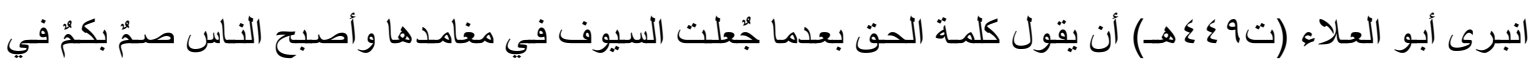

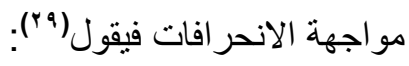

$$
\begin{aligned}
& \text { إذا حُبست أعظمى في الرحمْ }
\end{aligned}
$$

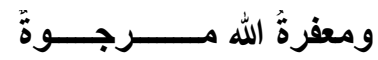

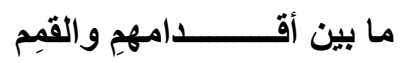

$$
\begin{aligned}
& \text { مجاورُ قومٍ تمشي الفنــــــــاءَ } \\
& \text { وليست جهالتـــــــهم بالأمم } \\
& \text { رأيتُ بني الدهرَ في غفلةٍ }
\end{aligned}
$$

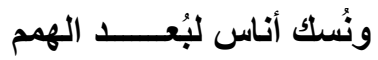

$$
\begin{aligned}
& \text { فنُسك الناس لضعف العقول }
\end{aligned}
$$

وينتقل الى المواجهة غير المباشرة بعد أن كلَّت الألسن في مناداة الناس وحثهم الى الطريق الصحيح فيقول(")."

$$
\begin{aligned}
& \text { عجلاً فهذا عالم منكــــــوس } \\
& \text { يا رب أخرجني الى دار الرضى } \\
& \text { من بعضها، فجميعها معكوس }
\end{aligned}
$$

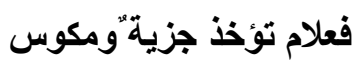

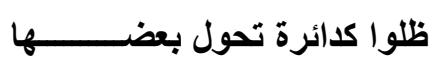

$$
\begin{aligned}
& \text { وأرى ملوكاً لا تحوط رعيـــة }
\end{aligned}
$$

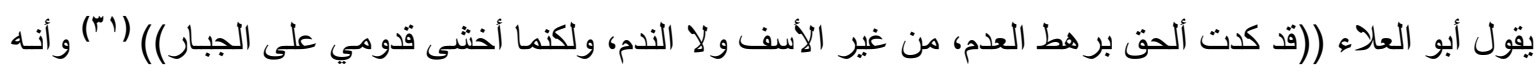

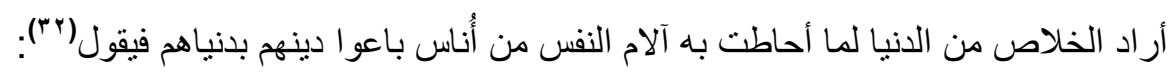

مخثية لاعتراها الناس أفواجا

يؤمها تاركاً للعيش أمواجا

من أن أعالج أثراء وأحواجـا تواجسا

$$
\text { لو لم تكن طرق هذا الموت موحثة }
$$

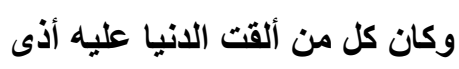

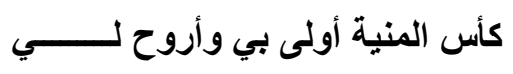

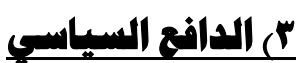

في ظل الظروف التي كانت في القرن الرابع الهجري ومـا آلت إليه الظروف السياسية من تمزق الدولـة العباسية

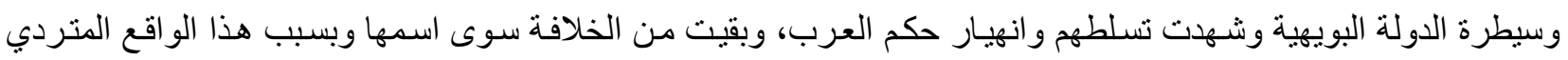

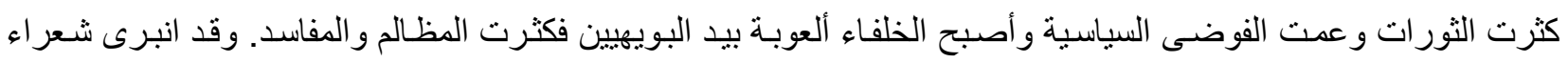
المواجهة لرفض هذا الو اقع المتردي فالمتنبي حمل لواء الرفض ومواجهة الحكام وفسادهم، واستنهاض قومهُُ والثورة عليهم بأسيافهم العطشى للاماء فيقول(بَ).

$$
\text { والطير جائعة لحم على وضم }
$$
أيملك الملك والأسياف ظامئة

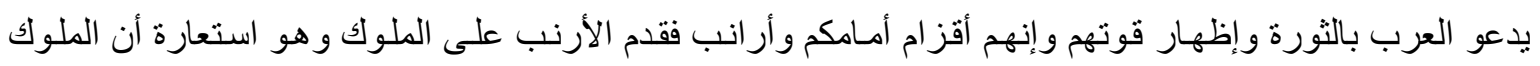

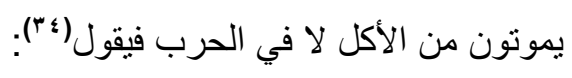

$$
\begin{aligned}
& \text { مفتحةّ عُيونهُم نيامُ } \\
& \text { أرانبُ غير أنهم ملولُّ } \\
& \text { وما أقرانها إلا الطعام } \\
& \text { بأجسام يحر القتلُ فيها }
\end{aligned}
$$

ويشتد الصراع عند المتنبي ووصلت عند الملوك بعدم الاهتمام بطبقة الثعب واستشر اء المجون و الفسوق و الترف الاف 


$$
\begin{aligned}
& \text { أهلُ الزمانِ وأهلُ كل زَمانِ } \\
& \text { وسعى فقََََّرَ عن مداهُفي العُلـــى } \\
& \text { أن السُروج مجالسنُ القتبـــــــانِ } \\
& \text { أنَخْذِوا المجالسنَ في البيُوتِ وعنَــده } \\
& \text { ـــهيجاءِ غَيرُ الطعن في الميدانِ }
\end{aligned}
$$

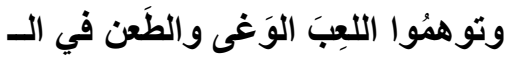

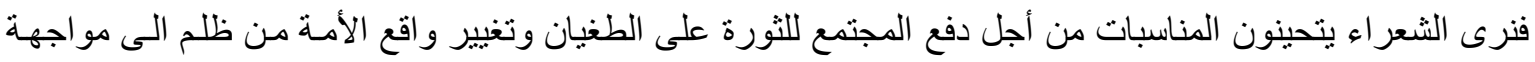

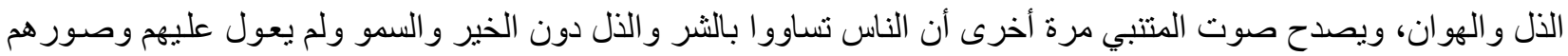

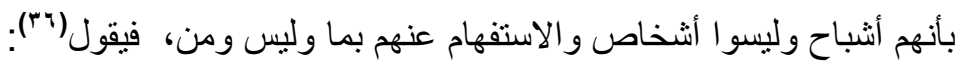

$$
\begin{aligned}
& \text { شر على الحُر من سُقٍِ على بلنٍ } \\
& \text { و إنما نحنُ فجاجيل سواسيـــــــةة } \\
& \text { تخُطيء إذا جئتَ في استفهامِها بمنِ } \\
& \text { حَولي بكلِمكانِ منهُهُ خلقِ }
\end{aligned}
$$

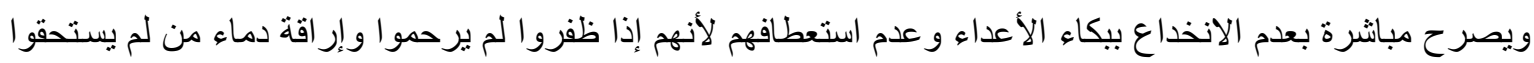

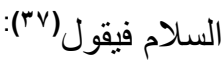

$$
\begin{aligned}
& \text { وأرحم شبابكت من عدُو ترحم }
\end{aligned}
$$

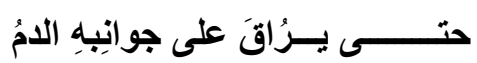

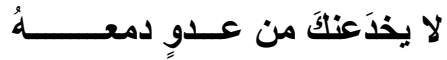

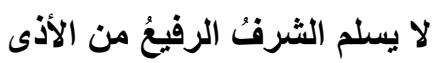

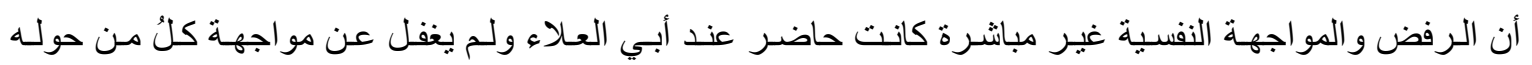

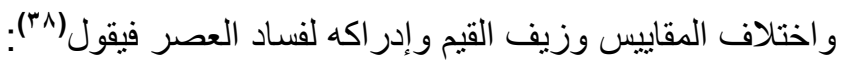

$$
\begin{aligned}
& \text { تجاهلت حتى ظُن أني جاهــــــــل } \\
& \text { لما رأيتُ الجهلَ في الناس فاشيـــــــاً } \\
& \text { ووا أسفاكم يظهر النقص فاضل } \\
& \text { وفاخرت الشهب الحصى والجنادل } \\
& \text { فوا عجباً كم يدعي الفضل ناقصن }
\end{aligned}
$$

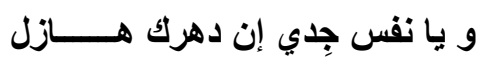

$$
\begin{aligned}
& \text { وقال السهـى للثمس أنت خفيــــــــة } \\
& \text { فيما موت زُر إن الحياة رخيصــــة }
\end{aligned}
$$

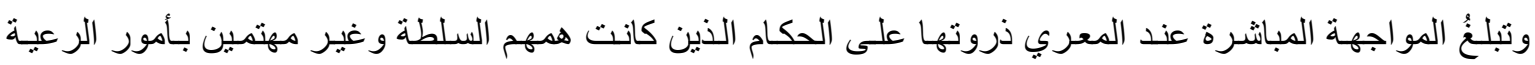

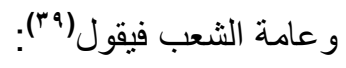

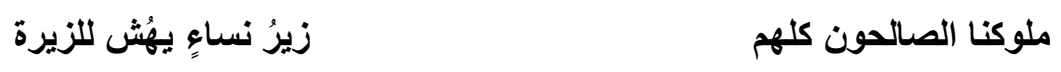

وأصبح الحكام لا يحملون سوى الاسم ويقتقون الى الحكمة والعقل في تدبير أمور البلاد ويتذمر الثـاعر منهم

$$
\text { فأفبٍ من الحياة وأفٍ منــي }
$$

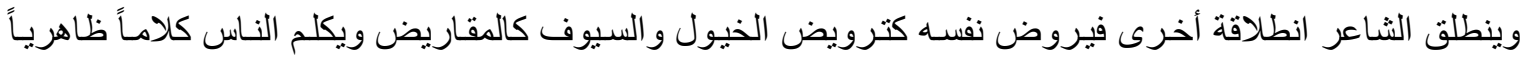

يخالف باطنهُ فيقول(1 ؛):

فما أصاحبُ صعب النفس ما ريضا

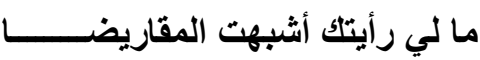

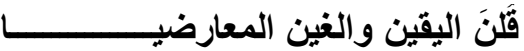

قد رُضت نفسِي حتى ذل جامحُها

يا ألسئنا كسيوف الهند خِلقَتهُها

إن الغُمود إذا سُّلّت صوارمهــا 


\section{ع) الدافع الذاتى}

إن الدافع الذاتي من أهم المحاور في هذا البحث ويأتي من النظرة الانسانية أي إن هذا الدافع دعا الثـاعر لمواجهة

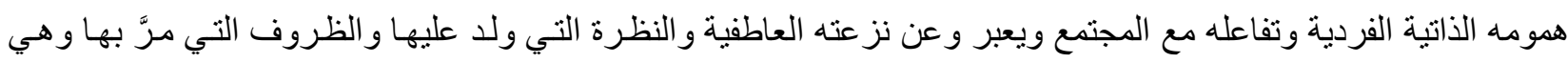

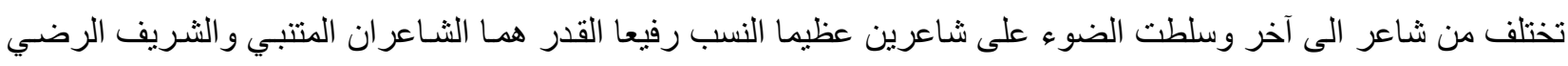

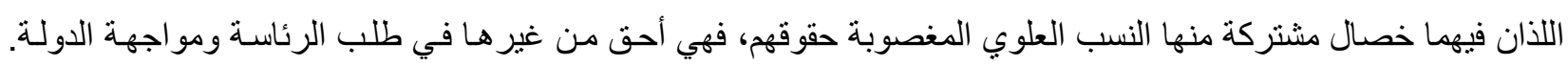

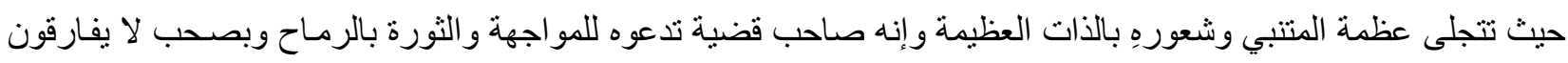

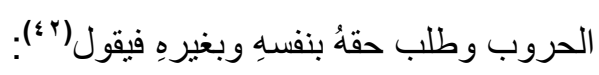

$$
\text { كََّّْهُ من طُول ما التثموا مُردُ }
$$$$
\text { سأطلب حقي بالقتا ومشايــخ }
$$

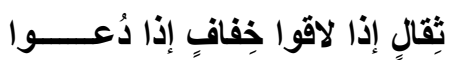

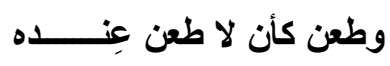

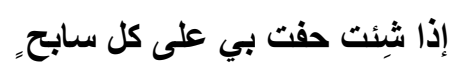

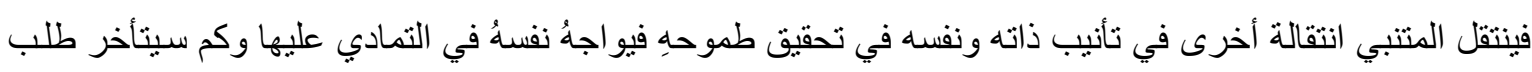

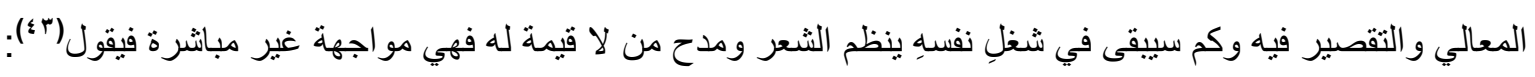

$$
\begin{aligned}
& \text { وكم هذا التمادي في التمادي } \\
& \text { الى كم ذا التخلف والتواني } \\
& \text { بييع الثعر في سوقي الكسادِ } \\
& \text { وشغلُ النفسِ عن طلب المعالي }
\end{aligned}
$$

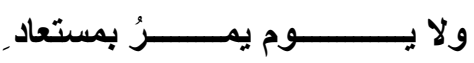

$$
\begin{aligned}
& \text { وما ماضي الثبــــــــــاب بمستَّرد }
\end{aligned}
$$

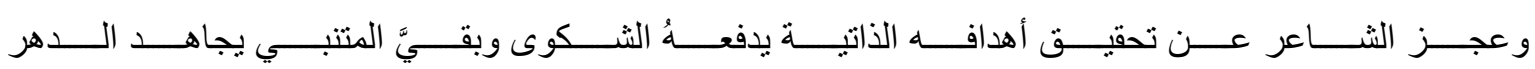

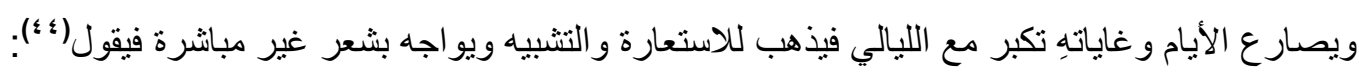

$$
\begin{aligned}
& \text { تطاردُني عن كونهـهـوأطارِدُ }
\end{aligned}
$$

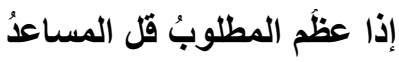

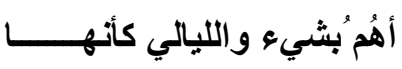

$$
\begin{aligned}
& \text { وحيداً من الخُلان في كل بلدةٍ }
\end{aligned}
$$

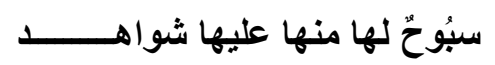

$$
\begin{aligned}
& \text { وتُسعدني في عمرةٍ بعد غمرةٍ }
\end{aligned}
$$

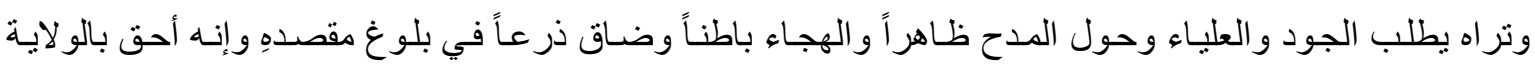
فيقول(0) ؛ ( )

فإنكا تُعطي في نداك المعاليـــا

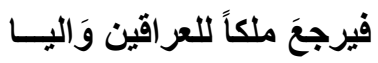

لسَائلتِ الفردِ الأي جاءَ عافيا

يرى كل فيَها وحاشَالََّ فانيا
إذا كسب الناسُ المعالي َالنـدى

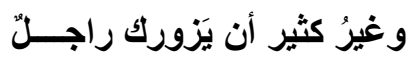

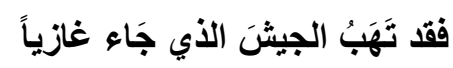

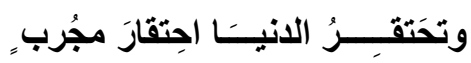

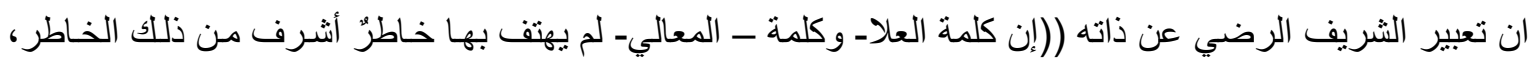

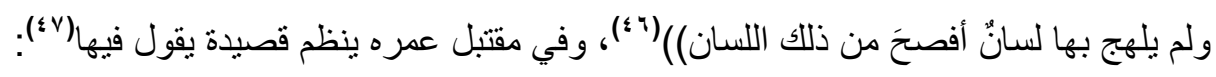

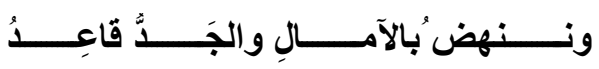
نصافي المعَاليَ و الزمان مُعْاندُ

ويذهب بمو اجهة غير مباشرة ويجعل من شعره سلوته الر افضة وذاته المتصدية للمعالي فيقول(^؛): 


\section{ويكتب ما تمُلي عليه المطامعُ \\ وكل فتنَ بالشعر تجلو هُمومهُ \\ وتخطي به دون العيون المسامع \\ وشعري تخصُ القلوبُ بحفِظه}

وتتجلى ذات الثريف الرضي في الحجازيات التي اخترعها الثـاعر و التعبير عن عمق احساسـه بالمكان الحجازي

و هو موطن الأهل و الأجداد والذكريات التاريخية وهو المحبب الذي يحمل القدية الدينية والإرث التاريخي وهو الموطن الذي

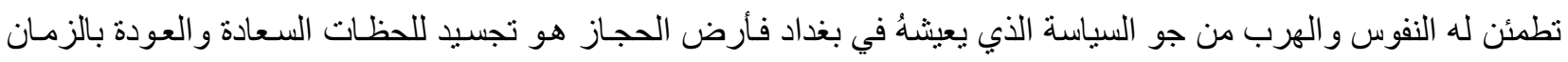

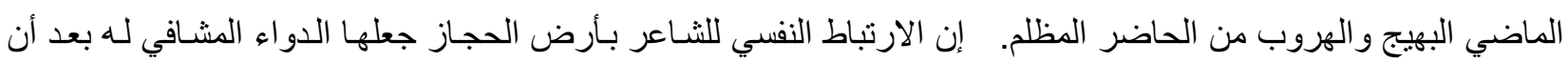
عجز دو اء العر اق من شفاءه فيقول(9 ؛)؛

وجدتمٍ بنجد لي طبيباً مُداويا

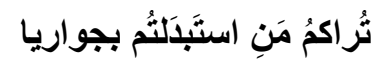

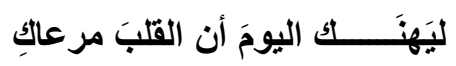

وليس يُرويك إلا مدمعي الباكي

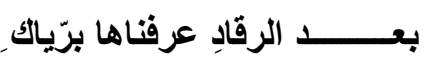

عــــى الرحالَ تعللنا بإِكرات

مــــنـن بالعراق لقد أبعدتِ مرماك لـاك
عَدِمت دوائي بالعراق فَرُبما

وقولوا لجيران على الخيف من مِنئً

ويقول في نص آخر (•):

يا ظبية البان ترعى في خمائِلــــــــهـ

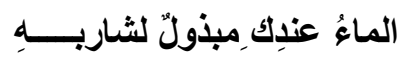

هَبّت لنا رياح الغورِ رائحسـة

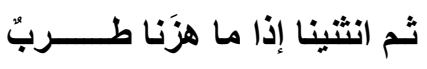

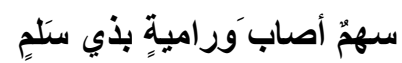

يُعد هذا النص من أثهر القصائد التي قالها الثريف الرضي و هي ظاهر ها الغزل الرقيق، و إن حقيقتها الغزل السياسي و التغزل بالخلافة فنقيب الأشر اف والحج و إن الذات التي عند الثاعر هو تأتره في الحجاز وتعويض الحلم المفقود الذي واجها

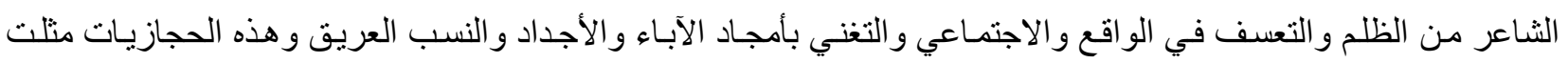

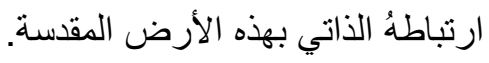

الخاتمة

خلاصة البحث أن مصطلح المواجهة هو مرتبط بالذات الانسانية ورفض كل ما يخالف النفس وتختلف المواجهة من نفسٍ الى نفس ومن مجتمع الى آخر ومن عصر الى عصر، والمواجهة هي انعكاس لواقع العصر بجميع جو انبه، ويكثف عن خو اطرهم من ظلم وفساد وذل وشعر المواجهة هو نتاج الظروف التي عانشها الثـاعر في هذا العصر ويترجم معاناة الثـاعر و هنالك عدة دو افع رئيسة دفعت الثعر اء للمو اجهة منها القومية، والدينية، والسياسية، والذاتية وجدت رفض الشعر اء في القرن الر ابع الهجري الذي كان و اقع العصر المضطرب وتسلق البويهيين وغيرهم وضعف الحكام وقيادة الدولة الاسـلامية من غير

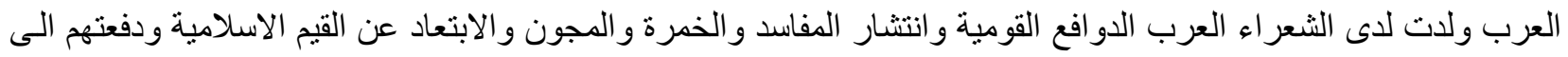

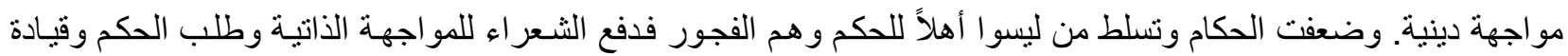

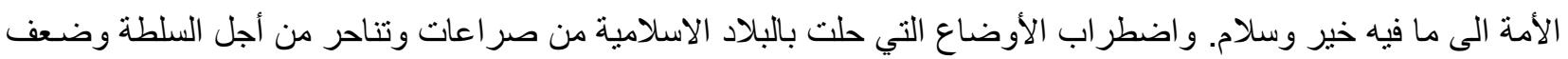

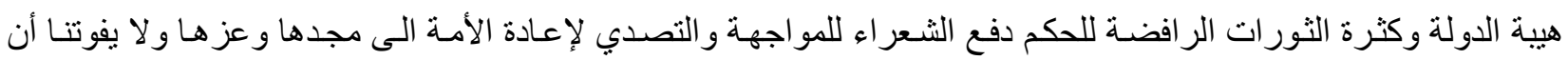
الشعر اء كانت لهم مواجهات منها مواجهة مباثرة وصريحة في الثعر والمجالس.

ومنهـا مو اجهات غير مباشـرة و غير صـريحة فتـارة يكون الغزل ظاهر هـا وباطنها الرفض وتـارة وصف الخيل

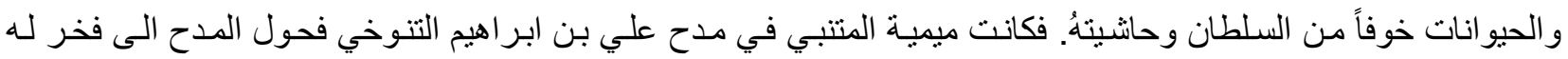

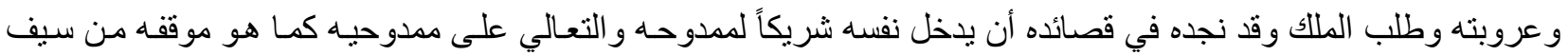


الدولة و اشترط أن يمدحهُ وهو جالس و هي غير عادة الممدوحين و الدافع العروبي والنسب الفاخر ومكانته الثخصية وحق

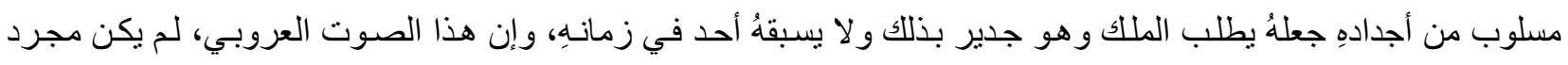

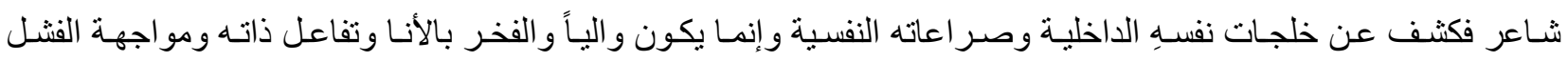
والإحباط لديه.

أما من جانب الثريف الرضي فهو يشترك مع المتنبي في أثنياء منها النسب العلوي الثريف والعروبـة العربية وحق

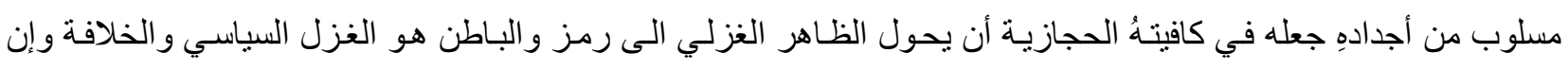

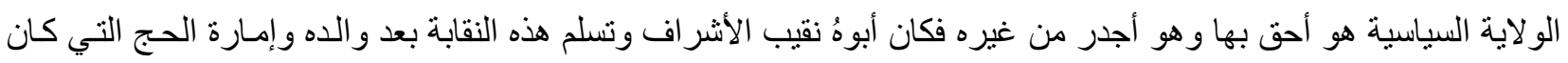
يشرف عليها وبقيت هذه الأمنيات هي أحلام لم تتحقق له وللمتنبي ونسأل الله أن نكون قد و وفقنا في بحثنا وفكرتنا هذه ون والله ولي

$$
\begin{aligned}
& \text { (1) (1) لسان العرب: مادة وجه، جr/ ص10. } \\
& \text { (ץ) الالتزام في الثعر العربي، د.أحمد أبو حاقة: صع ا. } \\
& \text { أمل دنقل أمير شعراء الرفض، نسيم مجلي، صبه. } \\
& \text { أديوان بان نباتة السعدي، تحقيق عبد الأمير الطائي/ج /صع ب ا. }
\end{aligned}
$$

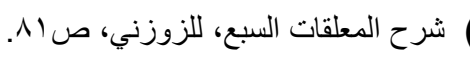

$$
\begin{aligned}
& \text { أدب المقاومة، غسان كنفاني، ص9. } \\
& \text { (V) شرح المعلقات السبع، للزوزني، ص9^. }
\end{aligned}
$$

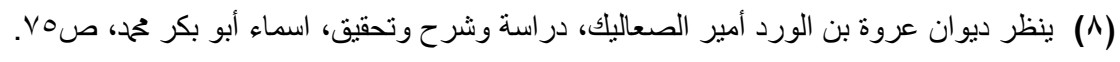

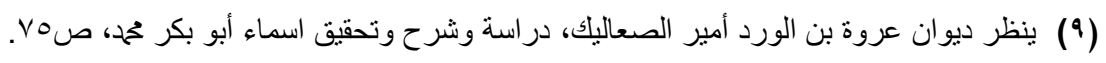

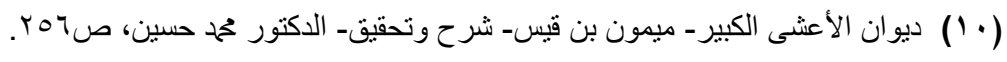

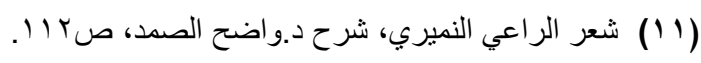

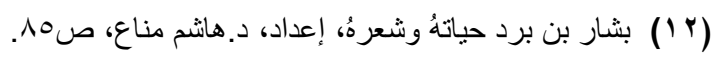

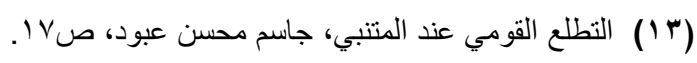

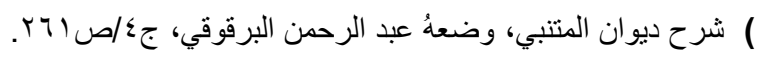

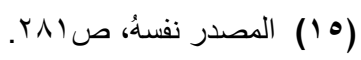

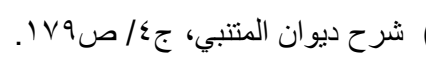

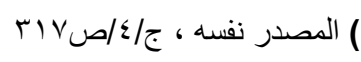

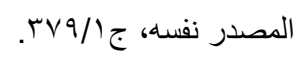

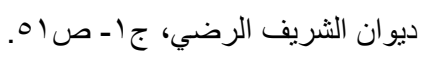

\section{- MIA.}




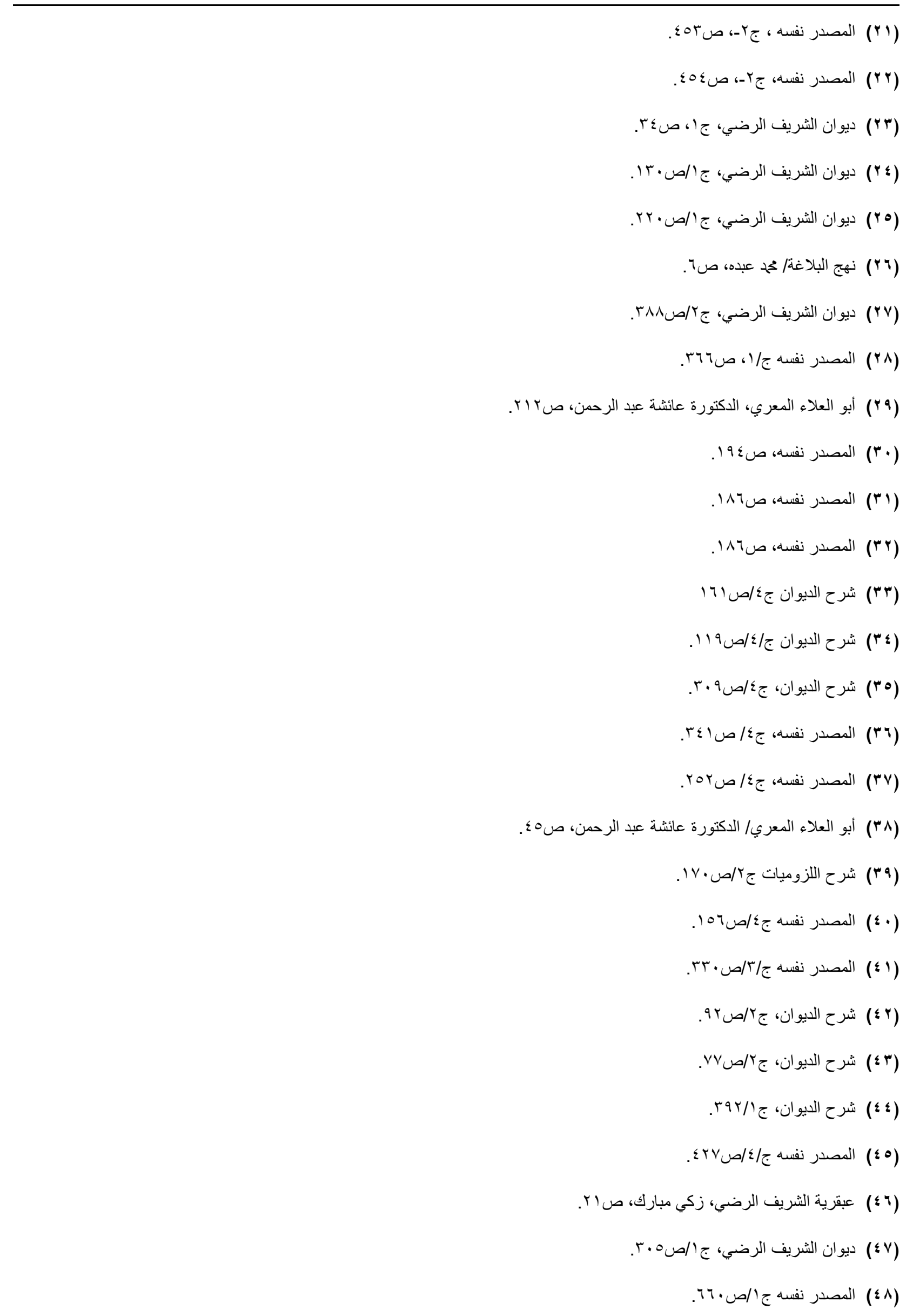


(

$.1 \cdot V /(0 \cdot)$

المصادر والمراجع

( ) أبو العلاء المعري، تأليف الدكتورة عائشة عبد الرحمن بنت الثاطي، النانر، وزارة الثقافة والارشاد القومي- المؤسسة المصرية العامة.

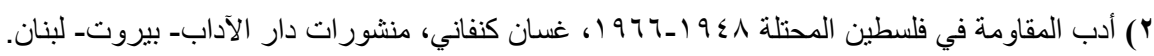
r) الالتزام في الثعر العربي، د.احمد أبو حاقة، طا، دار العلم للملايين.

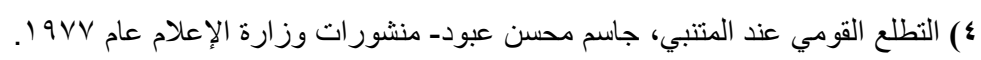
0) أمل دنقل ، أمبر شعر اء الرفض، نعيم مجلى، دار الجمهورية للصحافة. 9) بشار بن برد حياتهُ وشعره، إعداد: د. هانشم مناع، الناشر، دار الفكر العربي، الطبعة الأولى ع 99 (م. (V ديوان ابن نباته السعدي، تحقيق عبد الأمير الطائي، دار الحرية للطباعة. ^) ديو ان الثريف الرضي- صنعهُ، أبي حكيم الخيري، تحقيق عبد الفتاح حمد الحلو، الناشر وزارة الإعلام العر اقية. 9) ديو ان الأعثى الكبير، ميمون بن قبس- شرح وتحقيق محمد حسين، الناشر مكتبة الآداب بالجماهير، المطبعة النموذجية. • () ديوان عروة بن الورد، أمير الصعاليك، دراسة وشرح وتحقيق- اسماء أبو بكر حمد، منشورات دار الكتب العلمية- بيروت، لبنان 1911. 1) شرح اللزوميات، نظم أبي العلاء- احمد بن عبد الله بن سليمان المعري، تحقيق، زينب القوصي، وفاء الأعصر، د.سيدة حامد منير المدني، إثراف ومراجعة، الدكتور حسين نصار ، الناشر مركز تحقيق التراث. r r ا ) شرح المعلقات السبع ، للزوزني. ب ا ( ) شرح ديوان المتنبي، وضعه عبد الرحمن البرقوقوي، الناشر ودار الكتاب العربي، بيروت- لبنان. ؛ 1) شعر الراعي النميري، شرح، د.واضح الصمد، دار الجيل، بيروت، طا، الأولى، 1990. ه 1) عبقرية الثريف الرضي، د.زكي مبارك، الناثر المكتبة العصرية، بيروت، 7 . . r. 19 1) لسان العرب، ابن منظور، إعداد يوسف خياط، دار لسان العرب.

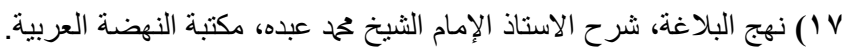

